\title{
Comparison of Source Apportionments of Fine Particulate Matter at Two San Jose Speciation Trends Network Sites
}

\author{
InJo Hwang \\ Center for Air Resources Engineering and Science, Clarkson University, Potsdam, NY \\ Philip K. Hopke \\ Department of Chemical and Biomolecular Engineering, Clarkson University, Potsdam, NY
}

\begin{abstract}
In this study, the chemical composition of fine particulate matter samples collected at U.S. Environmental Protection Agency Speciation Trends Network sites in San Jose, CA, from February 2000 to February 2005 were analyzed. A San Jose site was initially established at 4th Street and then subsequently moved to Jackson Street in mid-2002. These sites are $\sim 1 \mathrm{~km}$ apart. There were no known major changes in the nature of the sources in the area over this period. The study used positive matrix factorization model to extract the source profiles and their mass contributions and to compare the results for the congruence of the source apportionments between these two nearby sites. In the case of the 4th Street site, the average mass was apportioned to wood combustion (32.1 $\pm 2.5 \%)$, secondary nitrate $(22.3 \pm 2 \%)$, secondary sulfate $(10.7 \pm$ $0.6 \%)$, fresh sea salt $(7.7 \pm 0.9 \%)$, gasoline vehicles $(7.3 \pm$ $0.5 \%)$, aged sea salt $(6.8 \pm 0.4 \%)$, road dust $(6.7 \pm 0.7 \%)$, diesel emissions (3.9 $\pm 0.3 \%)$, and a Ni-related industrial source $(2.5 \pm 0.4 \%)$. At the Jackson Street site, the average mass was apportioned to wood combustion (33.6 \pm $2.6 \%)$, secondary nitrate $(20.3 \pm 1.9 \%)$, secondary sulfate $(13.9 \pm 0.9 \%)$, aged sea salt $(12.4 \pm 0.7 \%)$, gasoline vehicle $(8.3 \pm 0.6 \%)$, fresh sea salt $(5.3 \pm 0.5 \%)$, diesel emission $(3.2 \pm 0.3 \%)$, road dust $(1.9 \pm 0.1 \%)$, and Ni-related industrial source $(1.3 \pm 0.1 \%)$. Conditional probability function analysis was used to help identify local sources. These results suggested that moving the sampling site a short distance had little effect on the nature of the resolved source types although some differences in their quantitative impacts were obtained in the positive matrix factorization analyses.
\end{abstract}

\section{INTRODUCTION}

Emissions from a variety of sources have resulted in atmospheric pollution that, in turn, has produced serious problems, such as visibility degradation and acidic deposition on local and regional scales and climate change on

\section{IMPLICATIONS}

It is often necessary to move a monitoring site. This work shows that two nearby sites do provide similar source apportionment results so that there are data for trend analysis even with the site change. a global scale. ${ }^{1-3}$ Because particulate matter (PM) has adverse human health and welfare effects, $, 4,5$ many countries are developing and implementing environmental policies to control PM by establishing ambient air quality standards for PM. In 1997, U.S. Environmental Protection Agency (EPA) promulgated a National Ambient Air Quality Standards for PM with aerodynamic diameters $<2.5$ $\mu \mathrm{m}\left(\mathrm{PM}_{2.5}\right){ }^{6,7}$ To establish the relationship between PM concentrations and public health impacts, to understand PM temporal and spatial variations, and to understand source/receptor relationships, the Speciation Trends Network (STN) program was initiated by EPA in 2000. The STN consists of 54 long-term trends sites and $\sim 185$ supplemental sites. 6,7

To manage ambient air quality and establish effective emissions reduction strategies, it is necessary to identify sources and to apportion the ambient PM mass. To do so, receptor models have been developed that analyze various measured properties of the pollutants at the receptor site, identify the sources, and estimate their contributions. Many studies have applied these methods to assess the contribution of sources to enable reasonable ambient aerosol control.8-13 Among the multivariate receptor models used for PM source identification and apportionment, positive matrix factorization (PMF) has been developed $^{14}$ to provide an explicit least-squares technique. PMF has been shown to be a powerful technique relative to traditional multivariate receptor models. It has been successfully used to assess ambient PM source contributions at various locations. ${ }^{12,13,15-18}$

The objective of this study was to estimate the mass contributions and chemical composition of sources of $\mathrm{PM}_{2.5}$ at two STN sampling sites in San Jose, CA. PMF was applied to identify the sources and apportion the $\mathrm{PM}_{2.5}$ mass to each source. In addition, the conditional probability function (CPF) was applied to identify the predominant directions of local sources relative to surface wind direction. This study was used to compare the source contributions at each sampling site where the site has been relocated a short distance from the initial location. If the two sites both provide samples that are representative of the area, and the distance between sites is such that they are expected to reflect the same mix of sources, then the results of the source apportionments at the two sites should be similar and thereby provide a test of the source 


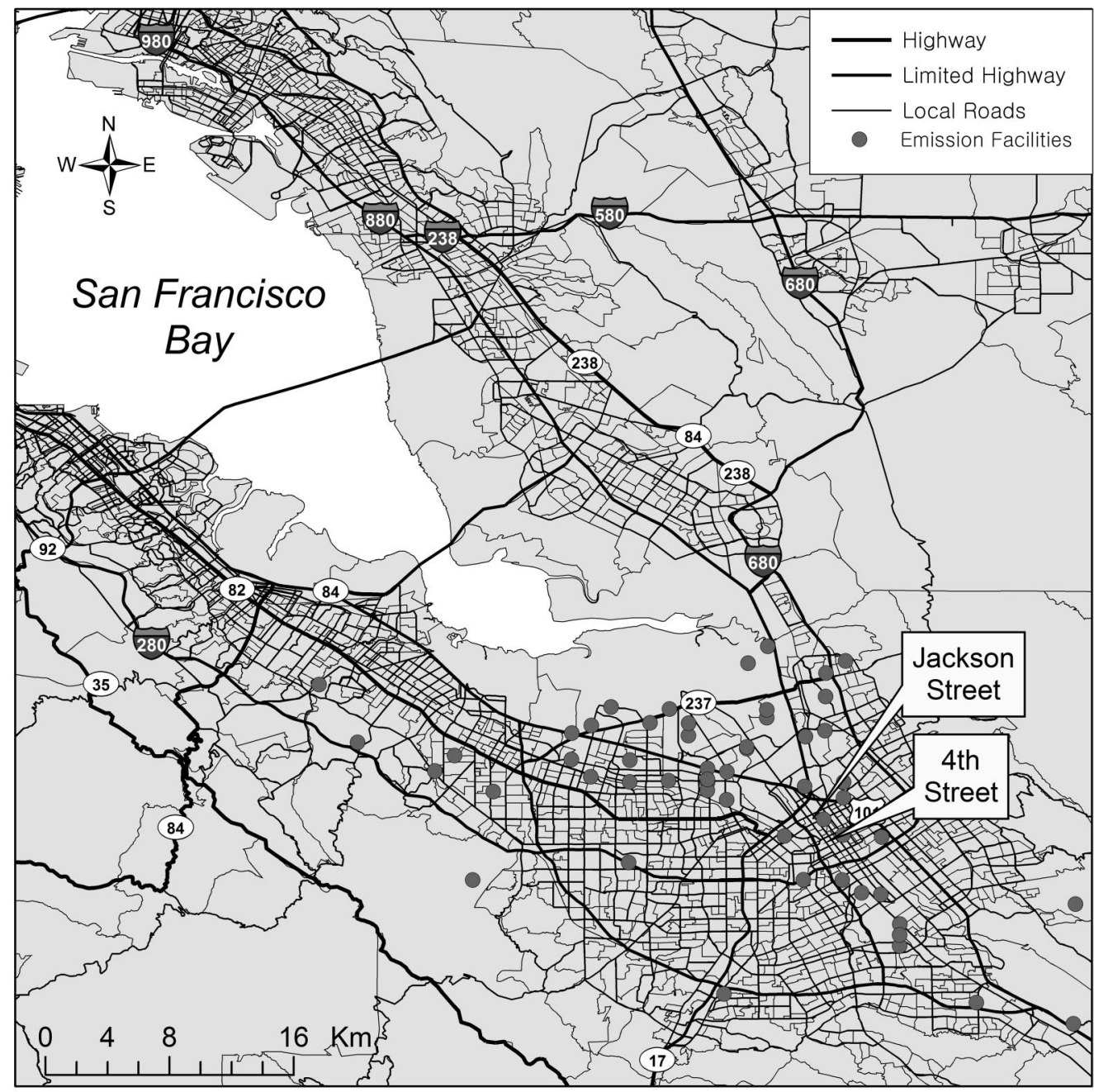

Figure 1. Location of the STN monitoring sites in San Jose (4th Street and Jackson Street).

apportionment methods to resolve and apportion the particle sources.

\section{EXPERIMENTAL WORK}

\section{Sample Collection and Analytical Methods}

$\mathrm{PM}_{2.5}$ samples were collected at the 4th Street and Jackson Street STN sites in San Jose (Figure 1). The location of the 4 th Street site (site ID: 60850004 ) is latitude $37.34^{\circ} \mathrm{N}$, longitude $121.89^{\circ} \mathrm{W}$, and the location of the Jackson Street site (site ID: 60850005) is latitude $37.35^{\circ} \mathrm{N}$, longitude $121.895^{\circ} \mathrm{W}$. These sites were located southeast of the San Jose International Airport. The distance between the Fourth Street site and the Jackson Street site is $\sim 1 \mathrm{~km}$. The 4th Street STN site was relocated to Jackson Street STN site in mid-2002. Highways and local roads are adjacent to the sites. The sampling sites are located $\sim 46 \mathrm{~km}$ east of the Pacific Ocean and $14 \mathrm{~km}$ southeast of the San Francisco Bay. The land use around the 4th Street site was residential, whereas for Jackson Street, the land use is primarily commercial. There are $\sim 122 \mathrm{PM}_{2.5}$ emitting facilities in the area according to the 1999 emissions inventory. ${ }^{19,20}$

The $\mathrm{PM}_{2.5}$ samples were collected on Teflon, Nylon, and quartz filters with a spiral aerosol speciation sampler
(Met One Instruments). ${ }^{21}$ The Teflon filters were used for the analysis of mass concentrations and elemental analysis (a total of 48 elements) by energy-dispersive X-ray fluorescence. The Nylon filters were used for the analysis of cations $\left(\mathrm{NH}_{4}{ }^{+}, \mathrm{Na}^{+}\right.$, and $\left.\mathrm{K}^{+}\right)$and anions $\left(\mathrm{SO}_{4}{ }^{2-}\right.$ and $\mathrm{NO}_{3}{ }^{-}$) by ion chromatography. The quartz filters were used for organic carbon (OC) and elemental carbon (EC) by thermal optical transmittance method. ${ }^{21,22}$ Samples were collected every 3 or 6 days, and a total of 221 samples were collected from February 2000 to May 2002 at the 4th Street site, and 230 samples were obtained from October 2002 to February 2005 for the Jackson Street site. Tables 1 and 2 provide the arithmetic mean, standard deviation, geometric mean, and minimum and maximum values for the measured species at two sampling sites.

\section{Receptor Modeling}

Factor analysis has been widely used in the air pollution research field to identify pollution sources. An explicit least-square approach called PMF can be written as ${ }^{14}$ :

$\chi_{\mathrm{ij}}=\sum_{\mathrm{k}=1}^{\mathrm{p}} g_{\mathrm{ik}} f_{\mathrm{kj}}+e_{\mathrm{ij}} \quad i=1, \ldots, n ; j=1, \ldots, m ; k=1, \ldots, p$ 
Table 1. Summary statistics for the $\mathrm{PM}_{2.5}$ and species concentrations at 4th Street, San Jose, during February 2000 to May 2002.

\begin{tabular}{|c|c|c|c|c|c|c|c|c|}
\hline \multirow[b]{2}{*}{ Species } & \multicolumn{8}{|c|}{ San Jose 4th Street $\left(\mathrm{ng} / \mathrm{m}^{3}\right)$} \\
\hline & $\begin{array}{l}\text { Arithmetic } \\
\text { Mean }\end{array}$ & $\begin{array}{l}\text { Standard } \\
\text { Deviation }\end{array}$ & $\begin{array}{c}\text { Geometric } \\
\text { Mean }\end{array}$ & Minimum & Maximum & $\begin{array}{c}\text { BDL } \\
\text { №. (\%) }\end{array}$ & MDL & $\begin{array}{c}\text { S/N } \\
\text { Ratio }\end{array}$ \\
\hline $\mathrm{PM}_{2.5}{ }^{\mathrm{a}}$ & 15.0 & 10.1 & 12.7 & 3.2 & 62.0 & - & - & - \\
\hline $\mathrm{OC}$ & 5605.0 & 4345.9 & 4643.0 & 1582.2 & 27992.2 & $1(0.5)$ & 0.244 & 5057.9 \\
\hline EC & 1064.0 & 911.4 & 815.4 & 114.2 & 5740.0 & $9(4.1)$ & 0.244 & 105.6 \\
\hline $\mathrm{NH}$ & 879.0 & 989.4 & 480.0 & 6.5 & 4780.0 & $11(5.0)$ & 0.017 & 1016.4 \\
\hline Al & 47.7 & 72.7 & 23.4 & 0.2 & 601.0 & $103(46.6)$ & 0.016 & 4.6 \\
\hline $\mathrm{Ba}$ & 55.7 & 28.2 & 46.8 & 1.8 & 145.0 & $62(28.1)$ & 0.035 & 5.0 \\
\hline $\mathrm{Br}$ & 3.5 & 2.3 & 2.7 & 0.2 & 11.7 & $71(32.1)$ & 0.002 & 5.3 \\
\hline $\mathrm{Ca}$ & 99.5 & 86.9 & 77.9 & 17.4 & 813.0 & $0(0.0)$ & 0.005 & - \\
\hline $\mathrm{Cl}$ & 251.8 & 385.3 & 74.7 & 0.7 & 2370.0 & 41 (18.6) & 0.008 & 151.5 \\
\hline $\mathrm{Mg}$ & 42.0 & 45.9 & 26.8 & 0.2 & 338.0 & $131(59.3)$ & 0.023 & 1.9 \\
\hline $\mathrm{Mn}$ & 3.6 & 3.2 & 2.5 & 0.1 & 19.8 & $100(45.2)$ & 0.002 & 3.0 \\
\hline $\mathrm{Na}^{+}$ & 633.0 & 489.1 & 479.4 & 43.2 & 2490.0 & $2(0.9)$ & 0.03 & 2306 \\
\hline $\mathrm{Ni}$ & 16.4 & 36.7 & 6.4 & 0.1 & 426.0 & $29(13.1)$ & 0.001 & 84.6 \\
\hline $\mathrm{Pb}$ & 5.5 & 10.5 & 3.6 & 0.1 & 143.7 & $138(62.4)$ & 0.005 & 1.2 \\
\hline $\mathrm{Si}$ & 163.2 & 196.7 & 111.5 & 18.0 & 1960.0 & $0(0.0)$ & 0.012 & - \\
\hline Sn & 17.8 & 7.0 & 16.2 & 1.9 & 35.6 & $126(57.0)$ & 0.018 & 1.0 \\
\hline $\mathrm{Sr}$ & 3.2 & 4.3 & 1.9 & 0.1 & 28.5 & $162(73.3)$ & 0.002 & 0.9 \\
\hline $\mathrm{Ti}$ & 9.1 & 7.2 & 7.1 & 0.5 & 56.4 & 38 (17.2) & 0.004 & 14.3 \\
\hline V & 2.0 & 1.6 & 1.4 & 0.1 & 9.0 & $168(76.0)$ & 0.002 & 0.5 \\
\hline $\mathrm{Zn}$ & 9.9 & 11.4 & 5.7 & 0.1 & 64.2 & $61(27.6)$ & 0.002 & 16.0 \\
\hline
\end{tabular}

Notes: ${ }^{a}$ Unit is $\mu \mathrm{g} / \mathrm{m}^{3}$.

where $x_{\mathrm{ij}}$ is the measured concentration in the $j$ th species in the $i$ th samples, $g_{i k}$ is the mass concentration of the $k$ th source contributing to the ith sample (i.e., source contributions), $f_{k j}$ is the mass fraction in the $j$ th species from the $k$ th source (i.e., source profiles), $e_{i j}$ is the portion of the measurements that cannot be fitted by the model (residuals), and $p$ is the total number of sources. PMF was implemented using the PMF2 program. ${ }^{14}$ PMF2 has been used in many studies. ${ }^{13,15,18,23-29}$ PMF depends on error estimates for each measured data value. ${ }^{27}$ Increased error estimates provide a useful method to reduce the weight of below detection limit (BDL) and missing values. Polissar et al. ${ }^{23}$ has suggested an approach for estimating the concentration values and their associated error estimates including BDL values and missing data, and this approach was used in this study. The measured concentrations below the method detection limit (MDL) values were replaced by half of the MDL values, and their uncertainties were set at five sixths of the MDL values. Missing concentrations were replaced by the geometric mean of the concentrations, and their accompanying uncertainties were set at four times this geometric mean concentration.

The parameter, FPEAK, was used to control rotations. By setting a nonzero value of FPEAK, the PMF2 is forced to add one $g$ vector to another and subtract the corresponding $f$ factors from each other, thereby yielding more physically realistic solutions. ${ }^{30}$ The $\mathrm{Q}$ values were plotted against the FPEAK value to explore the rotational space where only small changes in the $Q$ values are observed. It is also possible to use pairwise scatter plots of the $\mathrm{g}$ vectors to help define the FPEAK value. ${ }^{31}$ In this study, FPEAK values between -1 and 1 were examined, and an FPEAK value of 0 was selected.

\section{CPF}

To analyze local source impacts from various wind directions, the CPF values were calculated using source contribution estimates from PMF coupled with the wind direction values measured at the site. ${ }^{29}$ The sources are likely to be located in the directions that have high conditional probability values. To minimize the effect of atmospheric dilution, daily fractional mass contribution from each source relative to the total of all sources was used rather than the absolute source contribution. The same daily fractional contribution was assigned to each hour of a given day to match the hourly wind data. ${ }^{28}$ The CPF was described in detail by Kim and Hopke. ${ }^{29}$ In this study, the 15 sectors were used $\left(\Delta \Theta=24^{\circ}\right)$, and calm winds $(<1$ $\mathrm{m} / \mathrm{sec}$ ) were excluded from this analysis. The threshold value was set at the upper 25th percentile of the fractional contribution from each source.

\section{RESULTS AND DISCUSSION}

\section{Data Analysis}

For those cases where the $\mathrm{PM}_{2.5}$ mass concentration and/or all of the elemental concentrations were missing, the sample was excluded from the analysis. OC blank corrections were performed by using the regression of OC 
Table 2. Summary statistics for the $\mathrm{PM}_{2.5}$ and species concentrations at Jackson Street, San Jose, during 0ctober 2002 to February 2005.

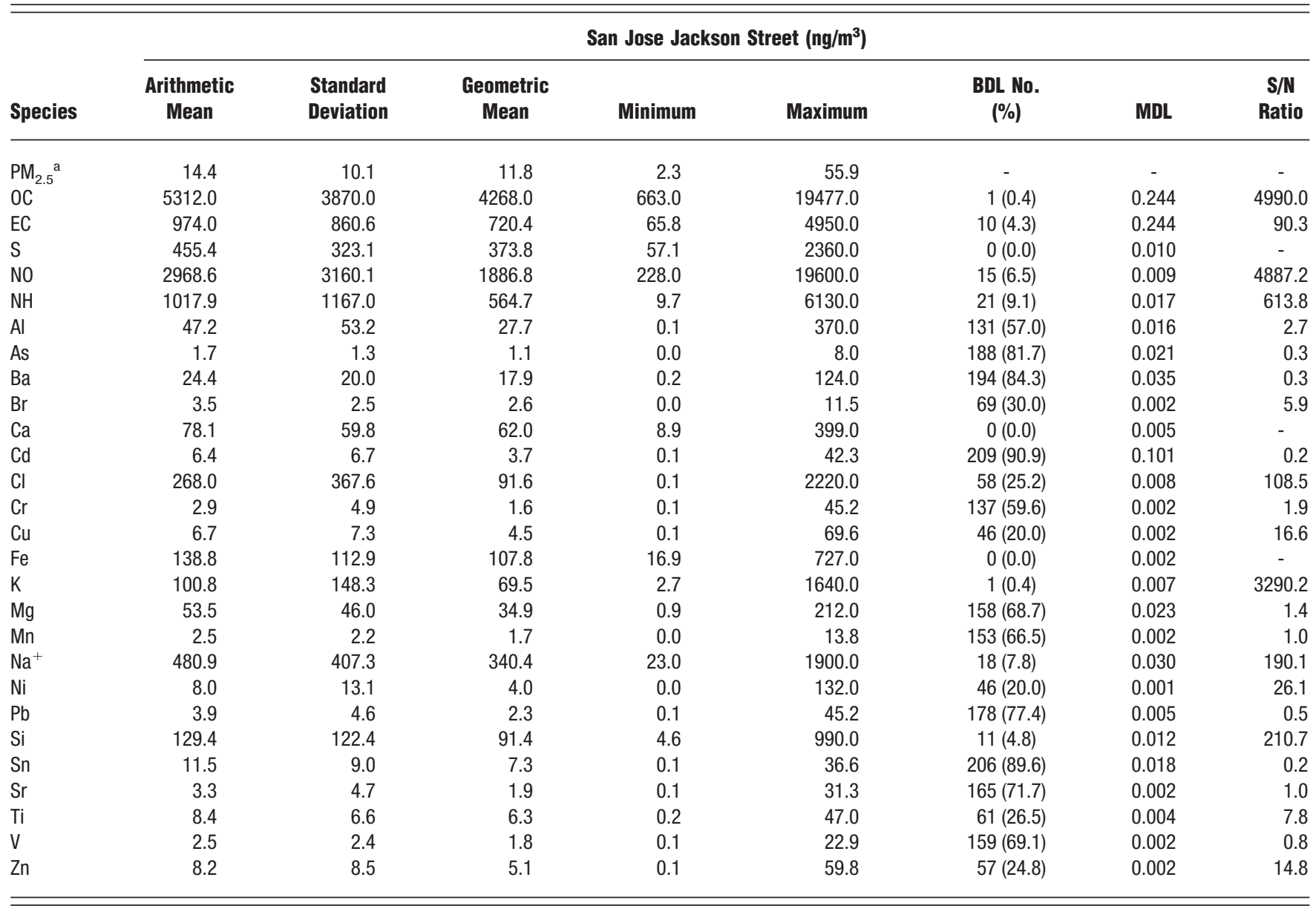

Notes: ${ }^{a}$ Unit is $\mu \mathrm{g} / \mathrm{m}^{3}$.

concentration against $\mathrm{PM}_{2.5}$ mass concentration. ${ }^{27,32} \mathrm{~A}$ reasonable blank estimate was obtained by calculating the intercept of the regression of OC concentration against $\mathrm{PM}_{2.5}$ mass concentration. The reported particulate OC concentrations were then blank corrected using these estimated OC blank values. To select the input variables, the signal-to-noise $(\mathrm{S} / \mathrm{N})$ ratios were calculated. ${ }^{33}$ Variables were defined to be a good, weak, or bad variables if $\mathrm{S} / \mathrm{N}$ ratio $\geq 2,0.2<\mathrm{S} / \mathrm{N}$ ratio $<2$, and $\mathrm{S} / \mathrm{N}$ ratio $\leq 0.2$, respectively. In this study, bad variables were excluded from the PMF model. Weak variables were downweighted by a factor of 2 or 3. For the 4th Street site, 25 species (OC, EC, S, $\mathrm{NO}_{3}{ }^{-}, \mathrm{NH}_{4}{ }^{+}, \mathrm{Al}, \mathrm{Ba}, \mathrm{Br}, \mathrm{Ca}, \mathrm{Cl}, \mathrm{Cr}, \mathrm{Cu}, \mathrm{Fe}, \mathrm{K}, \mathrm{Mg}, \mathrm{Mn}$, $\mathrm{Na}^{+}, \mathrm{Ni}, \mathrm{Pb}, \mathrm{Si}, \mathrm{Sn}, \mathrm{Sr}, \mathrm{Ti}, \mathrm{V}$, and $\mathrm{Zn}$ ) were selected, and the weak variables $(\mathrm{Cr}, \mathrm{Mg}, \mathrm{Pb}, \mathrm{Sr}, \mathrm{Sn}$, and $\mathrm{V}$ ) were downweighted. For the Jackson Street site, 27 species (OC, EC, $\mathrm{S}, \mathrm{NO}_{3}{ }^{-}, \mathrm{NH}_{4}{ }^{+}, \mathrm{Al}, \mathrm{As}, \mathrm{Ba}, \mathrm{Br}, \mathrm{Ca}, \mathrm{Cd}, \mathrm{Cl}, \mathrm{Cr}, \mathrm{Cu}, \mathrm{Fe}, \mathrm{K}$, $\mathrm{Mg}, \mathrm{Mn}, \mathrm{Na}^{+}, \mathrm{Ni}, \mathrm{Pb}, \mathrm{Si}, \mathrm{Sn}, \mathrm{Sr}, \mathrm{Ti}, \mathrm{V}$, and $\mathrm{Zn}$ ) were selected, and the weak variables (As, $\mathrm{Ba}, \mathrm{Cd}, \mathrm{Cr}, \mathrm{Mg}, \mathrm{Mn}$, $\mathrm{Pb}, \mathrm{Sr}, \mathrm{Sn}$, and $\mathrm{V}$ ) were downweighted. Tables 1 and 2 also present the MDL $\left(\mathrm{ng} / \mathrm{m}^{3}\right)$, number of BDL $(\%)$, and $\mathrm{S} / \mathrm{N}$ ratios for the species at the two San Jose STN sites.

\section{Source Contributions at 4 th Street}

The optimal number of sources was determined to be nine based on examination of the scaled residuals and the Q value. To estimate source contributions and source profiles in actual units for these matrices, scaling coefficients were obtained using a multiple linear regression against the measured $\mathrm{PM}_{2.5}$ mass. ${ }^{34}$ Figure 2 shows the source profiles obtained for the nine-factor PMF solution at 4 th Street, San Jose. Figure 3 presents the time series of contributions from each source. Table 3 provides a comparison of the seasonal contributions for each source and shows the average source contributions for the whole sampling period at 4 th Street, San Jose. The average source contributions for weekdays and weekend days for both sites are presented in Figure 4.

The species contributing to the first source included $\mathrm{OC}, \mathrm{EC}, \mathrm{NO}, \mathrm{K}, \mathrm{Fe}$, and $\mathrm{Mg}$. This profile was identified as wood combustion. As shown in the time series plot for this source (Figure 3), the highest level of wood combustion occurred in the winter, with particularly high contributions in the winter of 2001. Table 3 shows that the contributions during the winter were $\sim 2.3$ times higher than the contribution during the summer, and that mean weekend contributions were somewhat higher than weekday contributions (Figure 4), although there is not a statistical difference between the two. It might be anticipated that home heating with wood would be higher on weekends when the house is fully occupied for the entire day. This factor may also include some contributions 


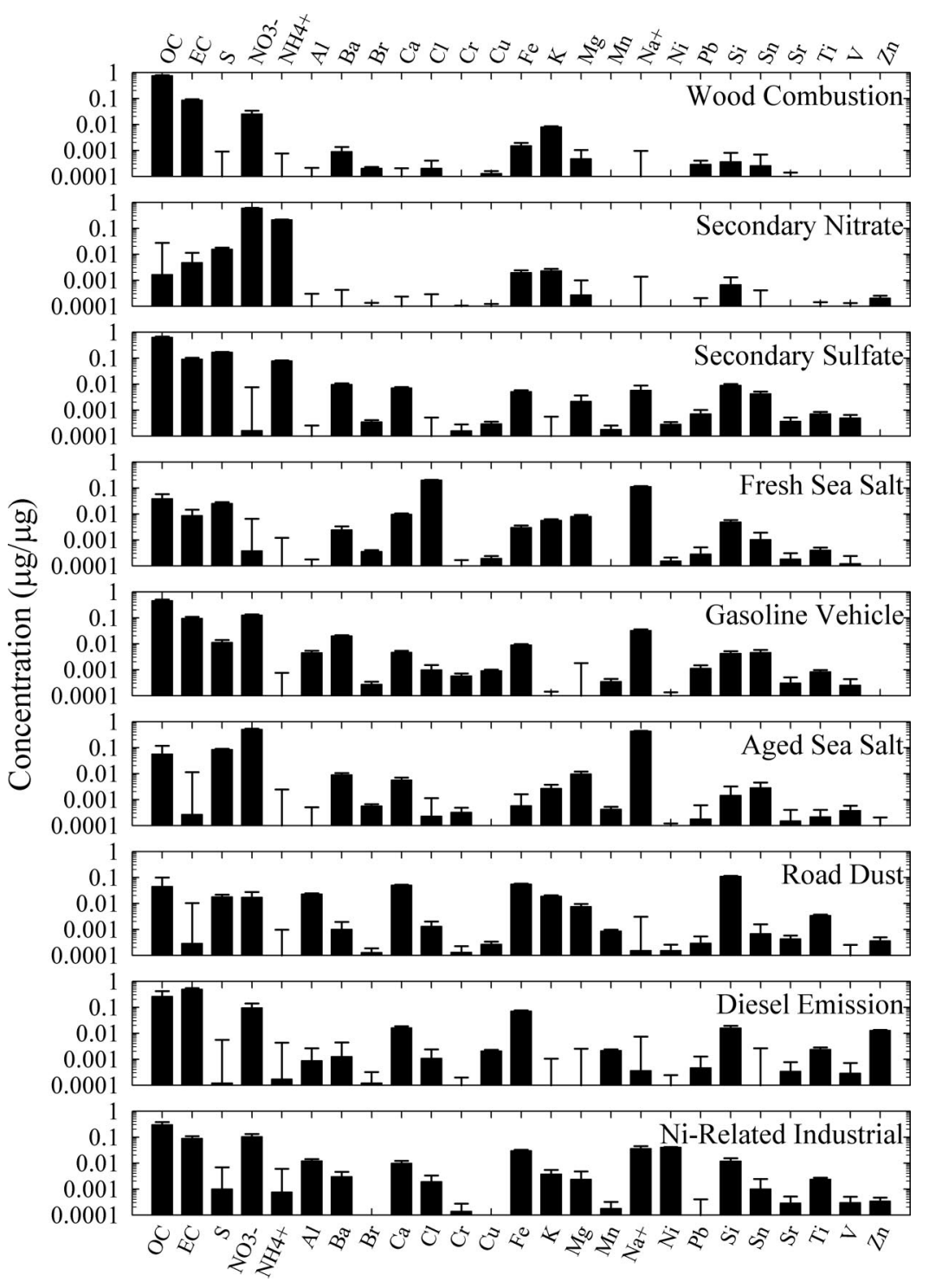

Figure 2. Source profiles for the 4 th Street STN site.

from meat cooking, because the combination of OC, EC, and $\mathrm{K}$ would also be the main marker species for this source type as well.

The major marker species contributing to the second source included $\mathrm{NO}_{3}{ }^{-}$and $\mathrm{NH}_{4}{ }^{+}$, and this profile was classified as secondary nitrate. The average mass contributions of secondary nitrate show a peak in winter. Mean weekday contributions were only slightly higher than weekend contributions (Figure 4).

The species associated with the third source included $\mathrm{S}$ and $\mathrm{NH}_{4}{ }^{+}$, and this profile was classified as secondary sulfate. The average seasonal mass contributions show peak contributions in the summer (Table 3). Because nitrogen oxide emissions (559.9 t/day) in the San Francisco Bay area were greater than oxides of sulfur emissions (71.6 t/day), it can be expected that the secondary nitrate contributions should be greater than the secondary sulfate contributions when cool temperatures conducive to secondary nitrate formation occur in the fall and winter. ${ }^{19}$ Figure 4 shows no significant difference between the concentrations measured on weekdays versus those measured on weekend days.

The species contributing to the fourth source included $\mathrm{Cl}, \mathrm{Na}^{+}, \mathrm{S}, \mathrm{Ca}, \mathrm{Mg}, \mathrm{K}$, and $\mathrm{Si}$. This source was identified as fresh sea salt. The peak seasonal mass contributions of fresh sea salt source were in the spring (Table $3)$. There was no difference between the concentrations measured on weekdays versus those measured on weekends (Figure 4).

The fifth source was interpreted as representing gasoline vehicle emissions. OC, EC, and $\mathrm{NO}_{3}{ }^{-}$were major species contributing to the fifth source along with minor species, such as $\mathrm{Ba}, \mathrm{Fe}, \mathrm{Sn}, \mathrm{Al}, \mathrm{Ca}$, and $\mathrm{Pb}$. This source was identified on the basis of high levels of OC and EC, with a higher proportion of OC. However, Shah et al. ${ }^{35}$ have shown that very slow moving and stop-and-go diesel vehicle emissions have OC/EC ratios that are very similar to those of gasoline vehicles. Thus, it is likely that this is a mixed source including gasoline and slow moving diesel vehicle emissions. The gasoline 


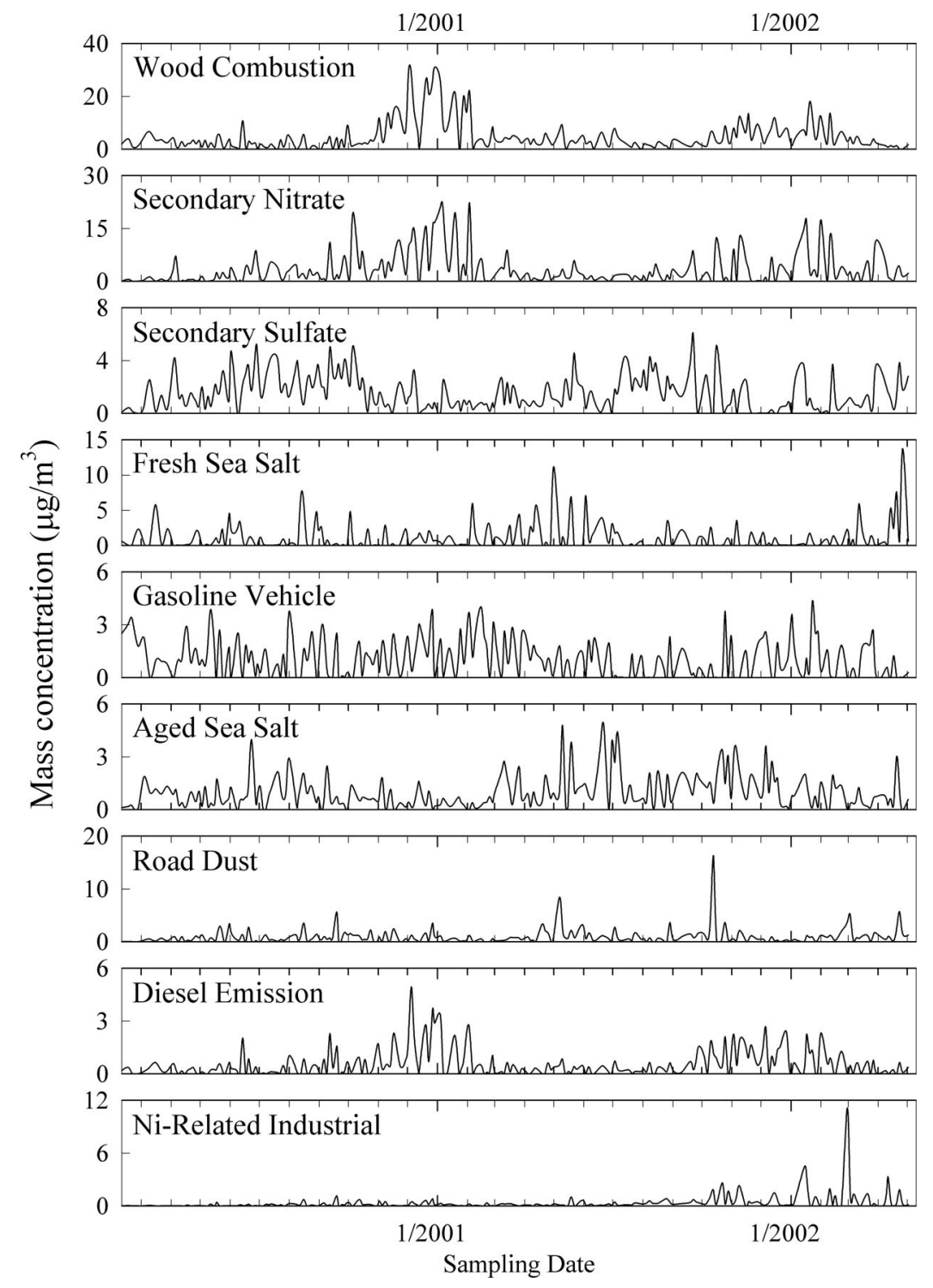

Figure 3. Temporal variation of source contributions for the 4th Street STN site.

vehicle emission contributions showed no difference among the seasons (Table 3). Weekday contributions of gasoline vehicle emissions were higher than the weekend contributions (Figure 4). These seasonal and weekend/weekday results support the assignment of sparkignition motor vehicle. It is surprising to observe a higher contribution from wood smoke than gasoline vehicles, but the strong seasonal pattern in the $\mathrm{K}$ concentrations supports this apportionment.

The sixth source was classified as the aged sea salt source. Although the main species in sea salt are known to be $\mathrm{Na}^{+}, \mathrm{Cl}, \mathrm{SO}_{4}{ }^{2-}, \mathrm{K}$, and $\mathrm{Ca},{ }^{36}$ only $\mathrm{Na}^{+}$showed a high level of source contribution with $\mathrm{S}$ and $\mathrm{NO}_{3}{ }^{-}$. The $\mathrm{Cl}$ was depleted, because $\mathrm{NaCl}$ is converted into $\mathrm{Na}_{2} \mathrm{SO}_{4}$ and $\mathrm{NaNO}_{3}$ by reaction of $\mathrm{NaCl}$ with gaseous $\mathrm{H}_{2} \mathrm{SO}_{4}$ and gaseous $\mathrm{HNO}_{3} \cdot{ }^{13,37,38}$ Aged sea salt showed relatively low contributions in all seasons (winter $0.70 \mu \mathrm{g} / \mathrm{m}^{3}$, spring $0.97 \mu \mathrm{g} / \mathrm{m}^{3}$, summer $1.27 \mu \mathrm{g} / \mathrm{m}^{3}$, and fall $1.11 \mu \mathrm{g} / \mathrm{m}^{3}$, respectively). Similar to the fresh sea salt contributions, the aged sea salt source showed no significant differences between weekdays and weekend days (Figure 4).
The major species contributing to the seventh source included $\mathrm{Si}, \mathrm{Fe}, \mathrm{Ca}, \mathrm{Al}, \mathrm{K}$, and $\mathrm{Mg}$, and this factor was assigned to be soil and road dust. The temporal variation of source contribution plot shows very strong contributions in October 2001, particularly October 13, 2001 (Figure 3). Examination of the back trajectories for October 13 suggests that the air mass was transported from the ocean to the west of the site. It is not known why there are such high contribution values for this source during this period. The weekday contribution of soil/road dust was higher than the weekend contribution (Figure 4), similar to the increased contribution of gasoline vehicles to the weekday samples.

The major species contributing to the eighth source included $\mathrm{OC}, \mathrm{EC}, \mathrm{NO}_{3}{ }^{-}, \mathrm{Fe}, \mathrm{Na}^{+}, \mathrm{Si}, \mathrm{Zn}, \mathrm{Ca}$, and $\mathrm{Cu}$. This source was assigned to diesel emissions. For diesel emissions, EC was higher relative to OC than was seen in the gasoline vehicle source profile. $\mathrm{Zn}$ and $\mathrm{Ca}$ are additives in motor oil, 36,39 and $\mathrm{Si}, \mathrm{Cu}$, and $\mathrm{Fe}$ are released from brake pads. ${ }^{40,41}$ The Fe can also be from muffler ablation. For diesel emissions, the winter $\left(1.09 \mu \mathrm{g} / \mathrm{m}^{3}\right)$ and fall $(0.79$ 
Table 3. Average seasonal source contribution using the PMF model in 4th Street, San Jose.

\begin{tabular}{|c|c|c|c|c|c|c|c|c|c|c|}
\hline \multirow[b]{2}{*}{ Profile Name } & \multicolumn{2}{|c|}{ Winter } & \multicolumn{2}{|c|}{ Spring } & \multicolumn{2}{|c|}{ Summer } & \multicolumn{2}{|l|}{ Fall } & \multicolumn{2}{|c|}{ Average } \\
\hline & $\mu g / m^{3} \pm S E$ & $\%$ & $\mu g / m^{3} \pm S E$ & $\%$ & $\mu g / m^{3} \pm S E$ & $\%$ & $\mu g / m^{3} \pm S E$ & $\%$ & $\mu g / m^{3} \pm S E$ & $\%$ \\
\hline Secondary nitrate & $5.79 \pm 0.94$ & 27.0 & $1.91 \pm 0.27$ & 16.5 & $1.99 \pm 0.24$ & 18.0 & $3.86 \pm 0.60$ & 24.4 & $3.29 \pm 0.30$ & 22.3 \\
\hline Secondary sulfate & $0.73 \pm 0.12$ & 3.4 & $1.47 \pm 0.12$ & 12.7 & $2.34 \pm 0.18$ & 21.2 & $1.84 \pm 0.22$ & 11.6 & $1.58 \pm 0.09$ & 10.7 \\
\hline Fresh sea salt & $0.76 \pm 0.15$ & 3.6 & $1.65 \pm 0.33$ & 14.2 & $1.30 \pm 0.25$ & 11.8 & $0.66 \pm 0.16$ & 4.2 & $1.13 \pm 0.13$ & 7.7 \\
\hline Road dust & $0.58 \pm 0.11$ & 2.7 & $1.17 \pm 0.18$ & 10.1 & $0.79 \pm 0.12$ & 7.1 & $1.41 \pm 0.35$ & 8.9 & $0.99 \pm 0.10$ & 6.7 \\
\hline Diesel emission & $1.09 \pm 0.16$ & 5.1 & $0.25 \pm 0.03$ & 2.2 & $0.27 \pm 0.05$ & 2.4 & $0.79 \pm 0.10$ & 5.0 & $0.57 \pm 0.05$ & 3.9 \\
\hline Ni-related industrial & $0.63 \pm 0.23$ & 3.0 & $0.27 \pm 0.07$ & 2.3 & $0.18 \pm 0.03$ & 1.6 & $0.45 \pm 0.08$ & 2.8 & $0.37 \pm 0.06$ & 2.5 \\
\hline Sum & $21.42 \pm 2.08$ & 100.0 & $11.62 \pm 0.58$ & 100.0 & $11.01 \pm 0.60$ & 100.0 & $15.81 \pm 0.98$ & 100.0 & $14.75 \pm 0.65$ & 100.0 \\
\hline
\end{tabular}

Notes: SE $=$ standard error

$\left.\mu \mathrm{g} / \mathrm{m}^{3}\right)$ contributions were higher than the spring $(0.25$ $\left.\mu \mathrm{g} / \mathrm{m}^{3}\right)$ and summer contributions $\left(0.27 \mu \mathrm{g} / \mathrm{m}^{3}\right)$. This increase may be the result of the lower mixed-layer heights in the winter relative to the rest of the year, and, thus, there is reduced dispersion of these ground level emissions. The weekday contribution of diesel emission was higher than the weekend contribution (Figure 4).

The final source was an unknown Ni-related industrial source. The species contributing to this source as markers included $\mathrm{OC}, \mathrm{EC}, \mathrm{NO}_{3}{ }^{-}, \mathrm{Fe}, \mathrm{Na}^{+}$, and $\mathrm{Ni}$. $\mathrm{Ni}$ is generally associated with oil combustion, ${ }^{13,26,42}$ but there was no $\mathrm{V}$ in this source profile. The average concentration of $\mathrm{Ni}$ over the sampling period $\left(16.35 \mathrm{ng} / \mathrm{m}^{3}\right)$ is much higher than the average concentration of $\mathrm{V}\left(2.02 \mathrm{ng} / \mathrm{m}^{3}\right)$ where $\mathrm{Ni}$ and $\mathrm{V}$ from residual oil combustion usually results in $\mathrm{V}$ concentrations that are two to three times the $\mathrm{Ni}$ values. Ni had a weak correlation with $\mathrm{V}(\mathrm{r}=0.2)$. This source was assigned to be some type of Ni-related industrial source. The contribution temporal variation plot shows very high values in February 2002 (Figure 3). There is no significant difference between the concentrations measured on weekdays versus weekend days (Figure 4).

\section{Source Contributions at Jackson Street}

The optimal number of sources in Jackson Street was also determined to be nine. Figure 5 shows the source profiles for the Jackson Street, San Jose, site. Figure 6 presents the contributions of each source to the $\mathrm{PM}_{2.5}$ mass. Table 4
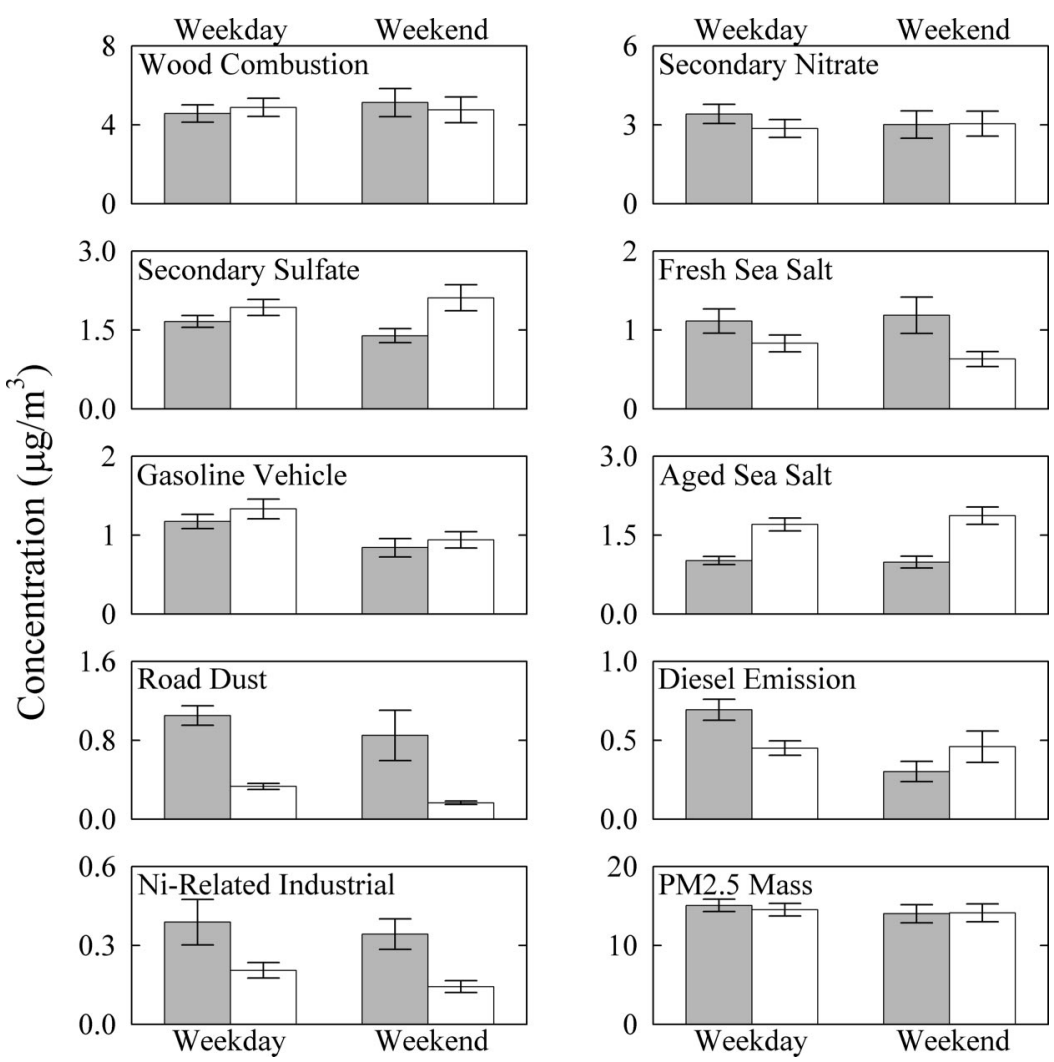

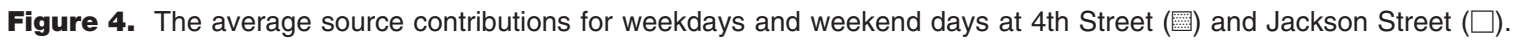




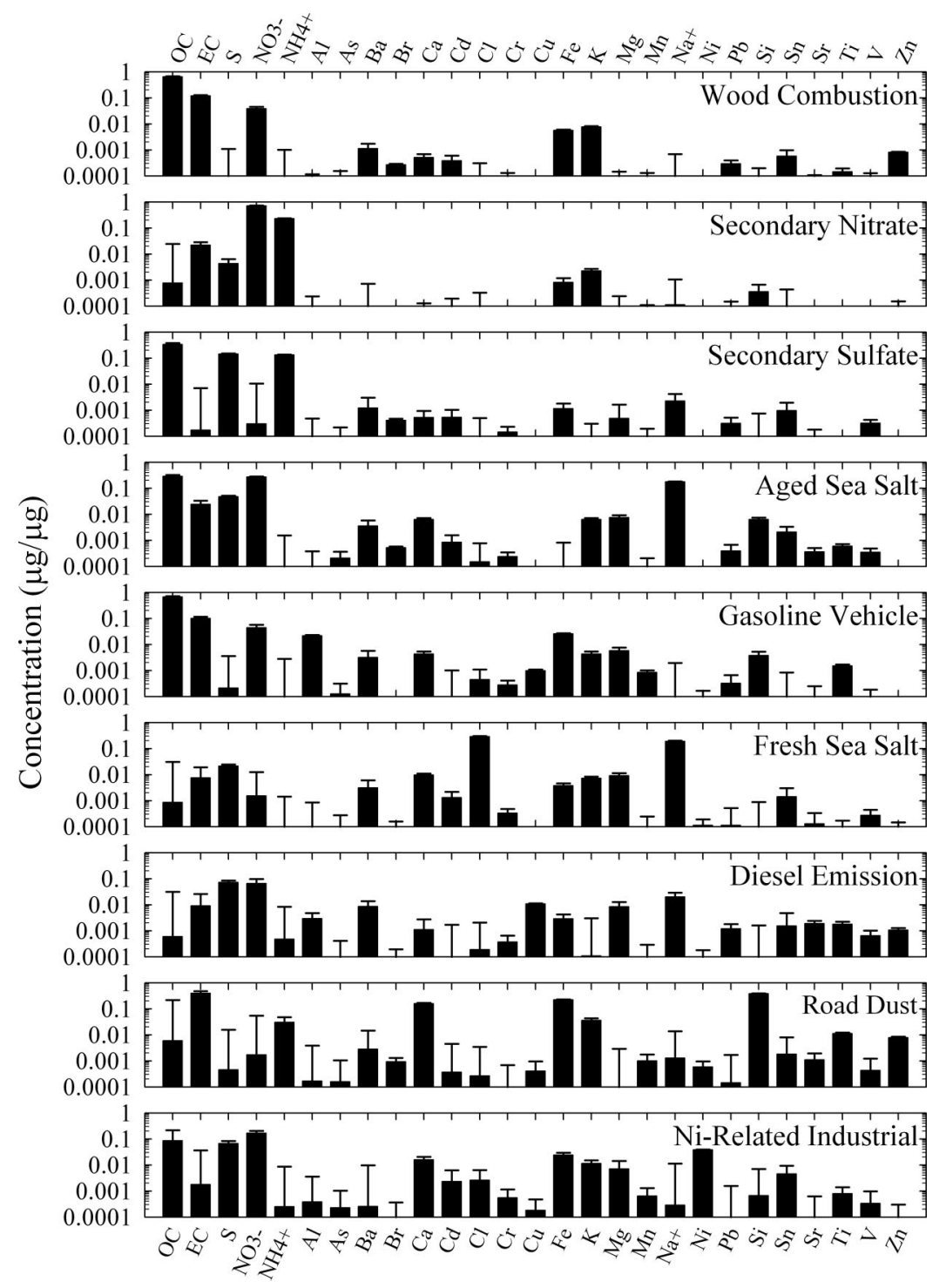

Figure 5. Source profiles for the Jackson Street STN site.

presents a comparison of seasonal contributions for each source and the average source contribution for the whole period of sampling using the PMF model at the Jackson Street site in San Jose.

The species contributing to the first source as markers included $\mathrm{OC}, \mathrm{EC}, \mathrm{NO}_{3}{ }^{-}, \mathrm{K}, \mathrm{Fe}$, and $\mathrm{Ba}$, and this profile was assigned to wood combustion. Again, the winter contributions were higher than the other seasonal contributions (winter $8.92 \mu \mathrm{g} / \mathrm{m}^{3}>$ fall $5.68 \mu \mathrm{g} / \mathrm{m}^{3}>$ spring 2.04 $\mu \mathrm{g} / \mathrm{m}^{3}>$ summer $\left.1.11 \mu \mathrm{g} / \mathrm{m}^{3}\right)$. At Jackson Street, there were no differences between the weekday contributions versus those for weekend days (Figure 4).

The species contributing to the second source are $\mathrm{NO}_{3}{ }^{-}, \mathrm{NH}_{4}{ }^{+}$, and EC. This source was identified as secondary nitrate with its peak contributions again in the winter. This source showed no weekend/weekday differences (Figure 4). The third source profile included S, $\mathrm{NH}_{4}{ }^{+}$, and OC. This source was assigned to be secondary sulfate. The high OC value was quite different from the profile observed at 4 th Street.
The presence of OC in the secondary sulfate profiles has been commonly observed in previous studies. ${ }^{13}$ It could presumably result from the condensation of organic matter on the sulfate particles in the more polluted urban environment. However, it could also result from the catalysis of the particle acidity in the formation of low volatility organic matter. ${ }^{43}$ The average contribution $\left(1.99 \mu \mathrm{g} / \mathrm{m}^{3}, 13.9 \%\right)$ was $\sim 1.3$ times higher than the secondary sulfate at the 4 th Street site $\left(1.58 \mu \mathrm{g} / \mathrm{m}^{3}\right.$, $10.7 \%)$, even though the average sulfur concentration was lower at Jackson Streets than observed at the 4th Street site. There appears to be some unknown influence of the site location in the nature of this profile leading to much higher OC and apportioned mass.

The fourth source was identified as the aged sea salt source. The major marker species is $\mathrm{Na}^{+}, \mathrm{OC}, \mathrm{NO}_{3}{ }^{-}, \mathrm{S}, \mathrm{EC}$, $\mathrm{Ca}$, and $\mathrm{K}$. The average aged sea salt source contributions were highest in the spring and lowest in winter (Table 4) with no differences between the weekday and weekend contributions (Figure 4). 

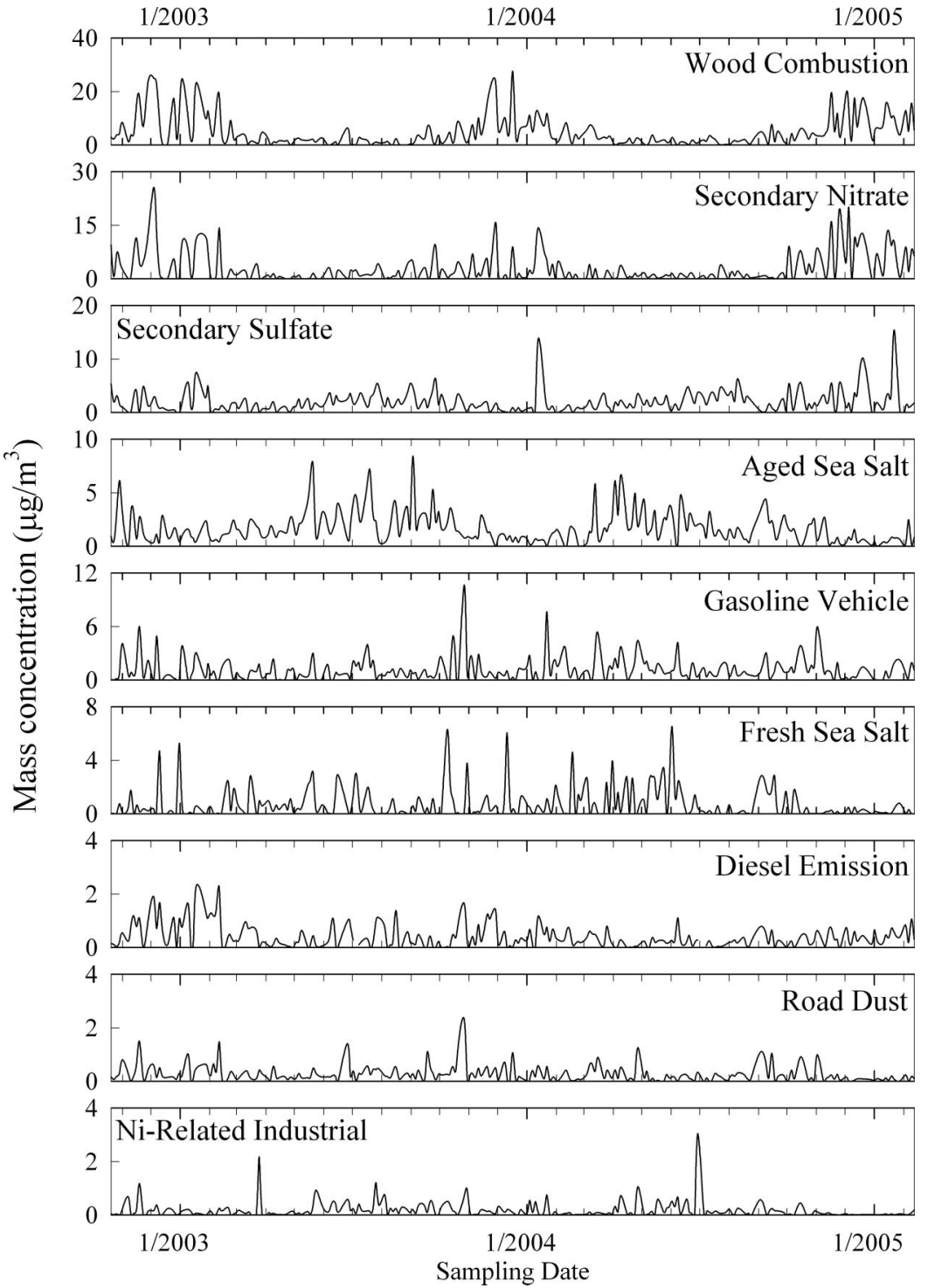

Figure 6. Temporal variation of source contributions for the Jackson Street STN site.

The fifth source was assigned to gasoline vehicle emissions. OC and EC were the major species contributing to this profile along with $\mathrm{NO}_{3}{ }^{-}, \mathrm{Al}, \mathrm{Fe}, \mathrm{Ba}, \mathrm{Ca}, \mathrm{K}$, and
Mg. Gasoline vehicle emissions contributions showed higher weekday values than those on the weekends (Figure 4).

Table 4. Average seasonal source contributions in Jackson Street, San Jose.

\begin{tabular}{|c|c|c|c|c|c|c|c|c|c|c|}
\hline Profile Name & $\mu g / m^{3} \pm S E$ & $\%$ & $\mu g / m^{3} \pm S E$ & $\%$ & $\mu g / m^{3} \pm S E$ & $\%$ & $\mu g / m^{3} \pm S E$ & $\%$ & $\mu \mathrm{g} / \mathrm{m}^{3} \pm \mathrm{SE}$ & $\%$ \\
\hline Wood combustion & $8.92 \pm 0.81$ & 46.8 & $2.04 \pm 0.23$ & 21.1 & $1.11 \pm 0.17$ & 11.1 & $5.68 \pm 0.73$ & 34.1 & $4.84 \pm 0.37$ & 33.6 \\
\hline Secondary nitrate & $4.77 \pm 0.67$ & 25.0 & $0.90 \pm 0.14$ & 9.3 & $1.27 \pm 0.17$ & 12.7 & $3.89 \pm 0.57$ & 23.4 & $2.92 \pm 0.28$ & 20.3 \\
\hline Secondary sulfate & $1.89 \pm 0.35$ & 9.9 & $1.38 \pm 0.12$ & 14.3 & $2.75 \pm 0.18$ & 27.4 & $1.99 \pm 0.22$ & 12.0 & $1.99 \pm 0.13$ & 13.9 \\
\hline Aged sea salt & $0.84 \pm 0.08$ & 4.4 & $2.40 \pm 0.24$ & 24.9 & $2.13 \pm 0.21$ & 21.2 & $1.95 \pm 0.20$ & 11.7 & $1.76 \pm 0.10$ & 12.4 \\
\hline Road dust & $0.23 \pm 0.03$ & 1.2 & $0.25 \pm 0.03$ & 2.6 & $0.23 \pm 0.03$ & 2.3 & $0.38 \pm 0.05$ & 2.3 & $0.27 \pm 0.02$ & 1.9 \\
\hline Diesel emission & $0.59 \pm 0.07$ & 3.1 & $0.24 \pm 0.03$ & 2.5 & $0.56 \pm 0.17$ & 5.6 & $0.39 \pm 0.05$ & 2.4 & $0.45 \pm 0.05$ & 3.2 \\
\hline Ni-related industrial & $0.10 \pm 0.02$ & 0.5 & $0.19 \pm 0.05$ & 2.0 & $0.29 \pm 0.06$ & 2.9 & $0.18 \pm 0.03$ & 1.1 & $0.18 \pm 0.02$ & 1.3 \\
\hline Sum & $19.08 \pm 1.61$ & 100.0 & $9.65 \pm 0.53$ & 100.0 & $10.04 \pm 0.50$ & 100.0 & $16.65 \pm 1.18$ & 100.0 & $14.38 \pm 0.65$ & 100.0 \\
\hline
\end{tabular}

Notes: SE $=$ standard error. 

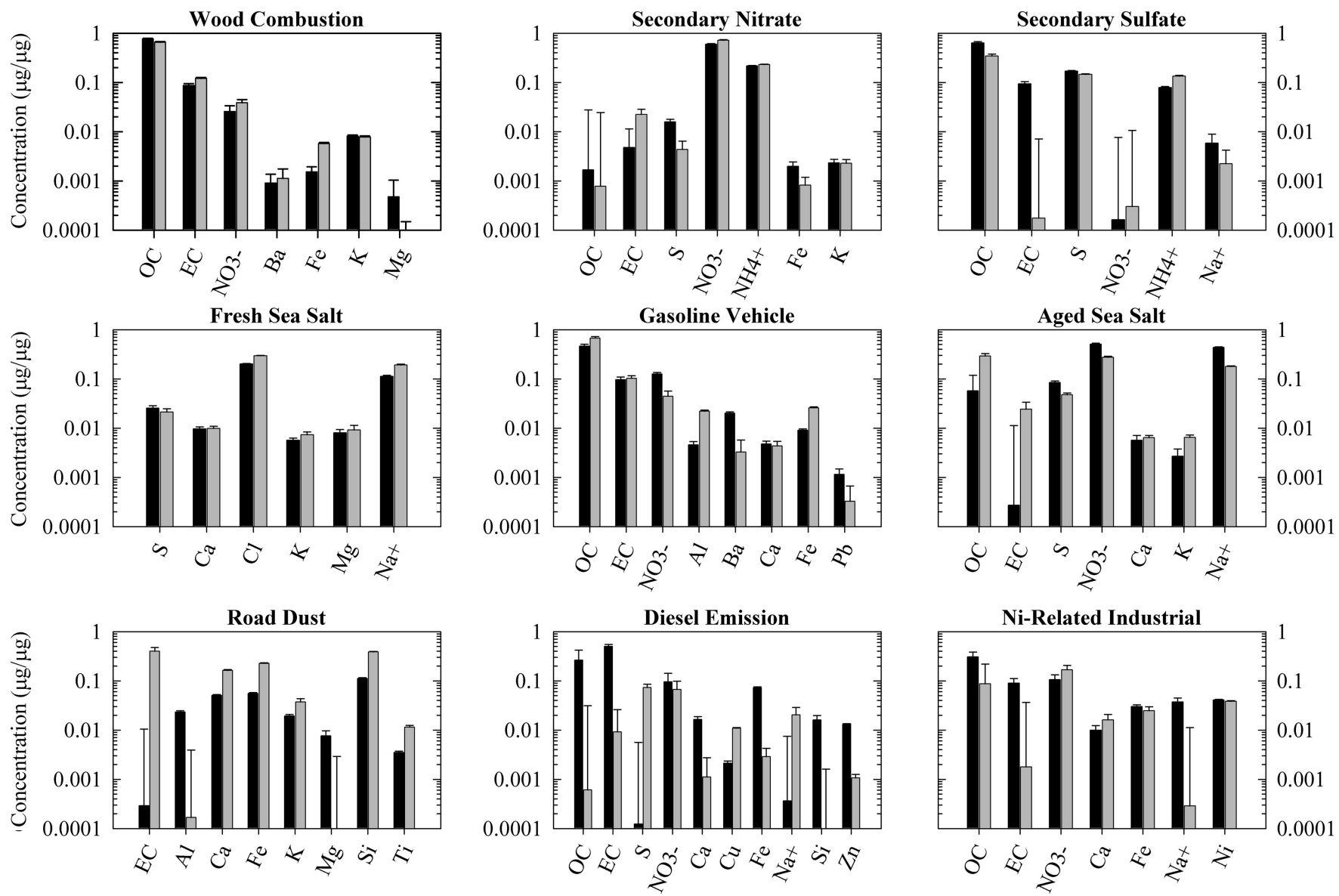

Figure 7. Comparison of source profiles resolved by PMF for 4th Street ( $\square$ ) and Jackson Street (圆).

The species contributing to the sixth source included $\mathrm{Na}^{+}, \mathrm{Cl}, \mathrm{Ca}, \mathrm{Mg}, \mathrm{K}$, and Fe. This factor was identified as fresh sea salt. The average seasonal mass contributions of fresh sea salt were similar to those of aged sea salt with a maximum in the spring and a minimum in the winter and no weekend/weekday difference.

The major species contributing to the seventh source included $\mathrm{EC}, \mathrm{OC}, \mathrm{NO}_{3}{ }^{-}, \mathrm{S}, \mathrm{Ba}, \mathrm{Cu}, \mathrm{Mg}, \mathrm{Na}^{+}$, and $\mathrm{Zn}$. This profile was classified as diesel emissions, although with different proportions of EC and OC compared with the 4th Street site diesel profile. EC is the primary pollutant emitted by diesel combustion. ${ }^{44}$ The temporal variation of diesel emissions showed fairly uniform values over the sampling period (Figure 6) with no seasonal differences (Table 4). There was no significant difference between the concentrations measured on weekdays versus weekend days (Figure 4). This is not consistent with diesel emissions and activity. This discrepancy requires further study in the future.

The major species contributing to the eighth source included $\mathrm{Si}, \mathrm{Fe}, \mathrm{Ca}, \mathrm{K}, \mathrm{EC}$, and Ti. This source was classified as road dust source. Temporal variation of road dust source shows uniform values during the sampling period except for the October 27, 2003, contribution (Figure 6). The back trajectory for this day showed air mass movement from the northeast with the trajectory moving backward over Eastern Oregon before bending westward to the ocean over Southern Washington. However, the exact nature of this event is not known. Given the location in a more commercial area, there could also be an increased contribution from construction activity. The contributions showed only small differences among the seasons with a small increase in the fall. The weekday contributions of soil source were higher than the weekend contributions (Figure 4), probably as a result of the higher traffic levels on weekdays.

Finally, the ninth source was again an unknown Nirelated industrial source. The species contributing to this source as markers included $\mathrm{NO}_{3}{ }^{-}$, OC, $\mathrm{S}, \mathrm{Ni}, \mathrm{Fe}, \mathrm{Ca}$, and $\mathrm{Sn}$. The mass contribution of Ni-related industrial source showed a weak peak in the summer. Weekday contribution was higher than the weekend contribution (Figure 4).

\section{Comparison of the 4th Street and Jackson Street Results}

This study applied PMF to data from two sampling sites (former and relocated site). Nine sources were found at both sites: wood combustion, secondary nitrate, secondary sulfate, fresh sea salt, gasoline vehicle, aged sea salt, road dust, diesel emission, and Ni-related industrial source, respectively. Figure 7 shows the comparison of resolved source profiles for the 4 th Street (dark bar) and Jackson Street (gray bar). The comparison of source profiles for each source used only the major marker species and species making high contributions to the mass of that source. In the case of wood combustion, secondary nitrate, secondary sulfate, fresh sea salt, gasoline vehicle, aged sea salt, and Ni-related industrial source profiles of 

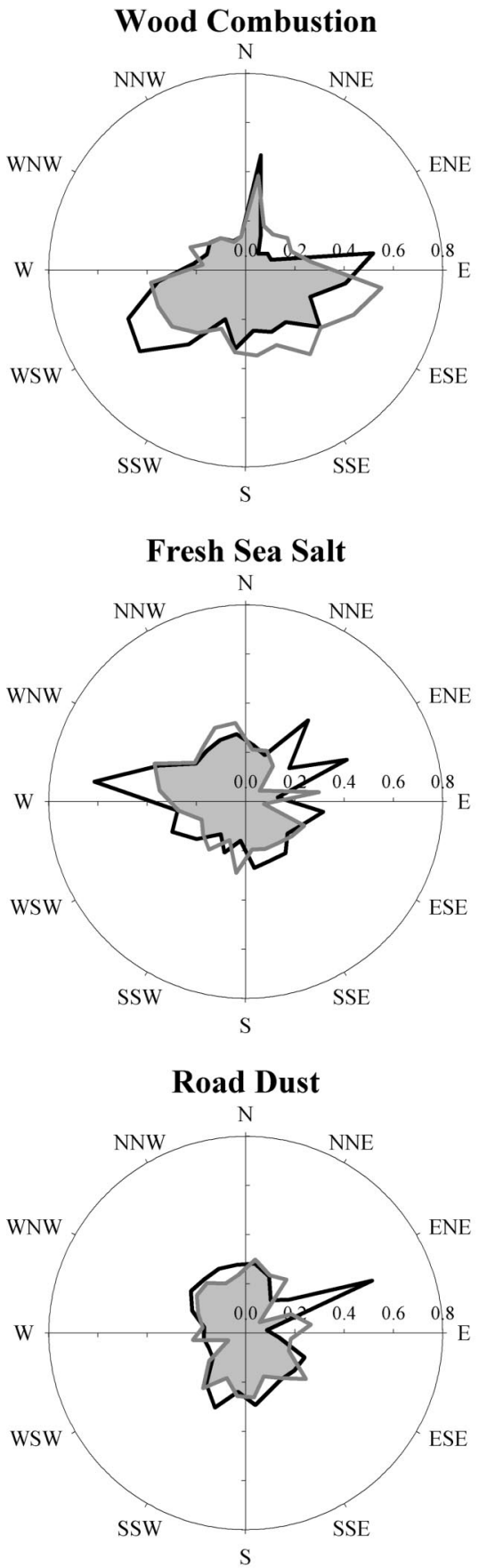
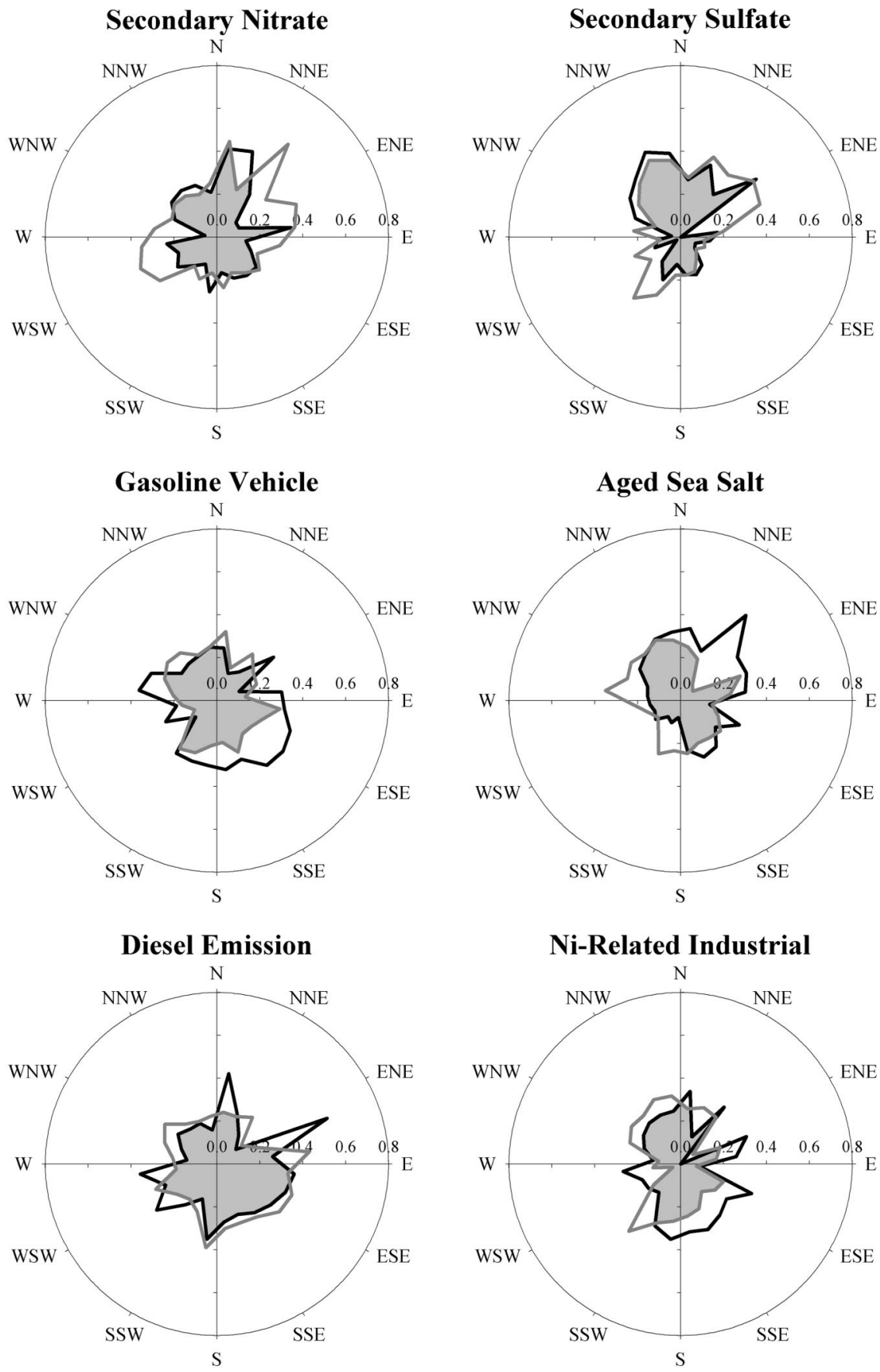

4th St.

Jackson St.

Figure 8. CPF results based on source contributions obtained by the PMF analysis of the data from 4th Street (dark line) and Jackson Street (gray line) in San Jose (gray areas denote overlap area between 4th Street and Jackson Street).

these sources showed good agreement between the two sampling sites. However, the source profiles for road dust and diesel emissions showed some significant differences for several species. Study beyond the scope of the present work will be needed to obtain an understanding of these differences between the source profiles.

The CPF plots in 4th Street (black line) and Jackson Street (gray line) are presented in Figure 8. In Figure 8, the gray areas denote the area of overlap between the 4 th
Street and the Jackson Street results. The CPF plot indicated wood combustion sources located to the east, south, west-southwest, and north (weak) as shown in Figure 8. In the case of $\mathrm{PM}_{2.5}$ emission inventory in this area, residential wood combustion is the highest source of $\mathrm{PM}_{2.5}$, especially in the winter. ${ }^{19,45,46}$

The CPF plot indicated secondary nitrate, gasoline vehicle, and diesel emission sources to the north, northeast, west, and south as shown in Figure 8. These sources are 

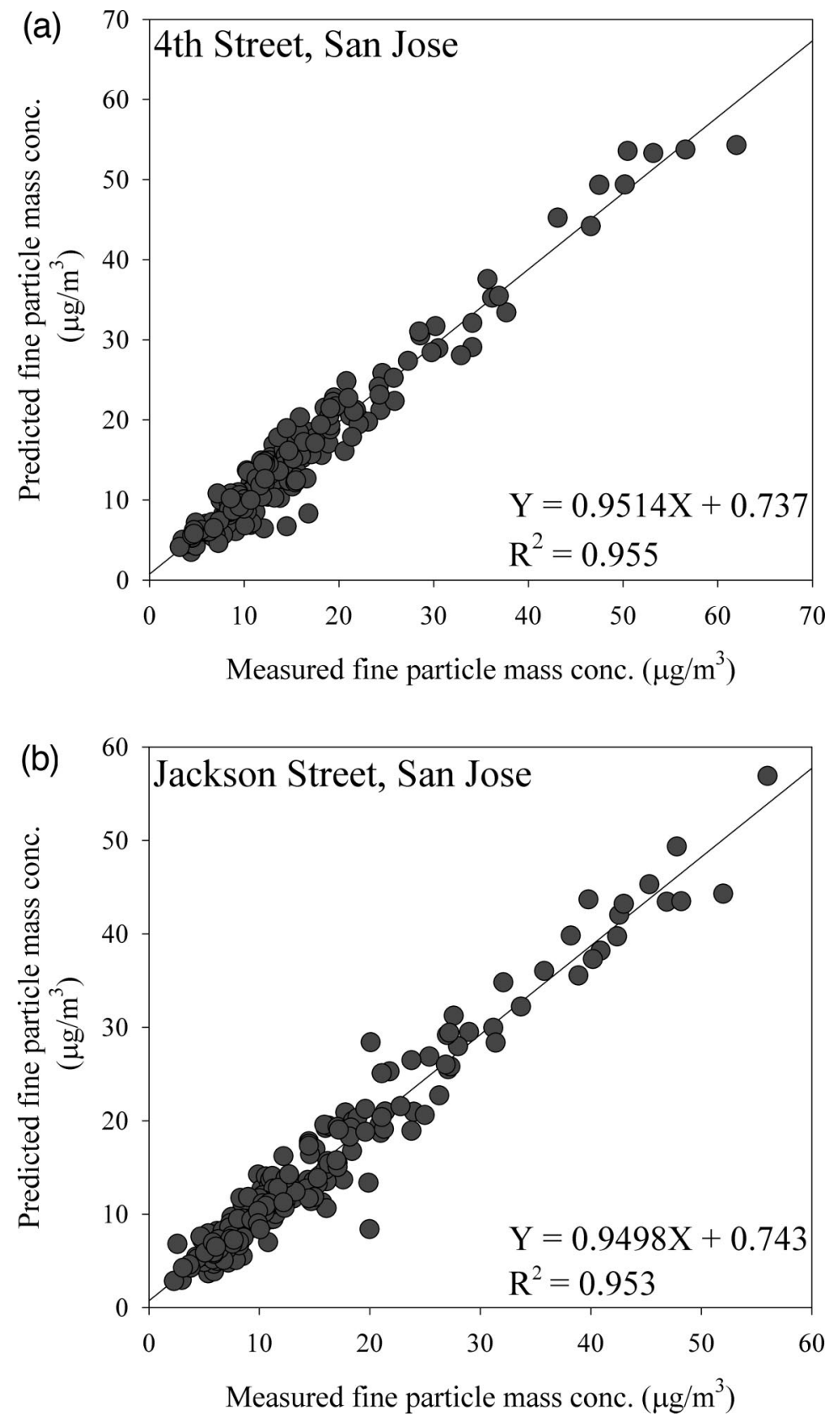

Figure 9. Comparison of the predicted total $\mathrm{PM}_{2.5}$ mass concentrations from the PMF analysis with measured $\mathrm{PM}_{2.5}$ mass concentrations for (a) 4th Street and (b) Jackson Street sites.

related to on-road and off-road vehicle emissions. Because highways and local roads are adjacent to each of the sites, it can be anticipated that they would affect the apparent directions from which the emissions come to the site.

The CPF plot indicated secondary sulfate sources to the north, northeast, and northwest as shown in Figure 8. The $\mathrm{SO}_{2}$ that emitted various sources was converted $\mathrm{H}_{2} \mathrm{SO}_{4}$ into $\mathrm{SO}_{4}{ }^{2-}$. In this area, the largest sources of $\mathrm{SO}_{2}$ were ships and petroleum refineries. ${ }^{19}$ Because the six petroleum refineries are located to the north of the sampling site and ships are frequently operating in northern areas of San Francisco Bay, this result is consistent with secondary sulfate originating from these relatively nearby sources.
The CPF plots indicated that sea salt (fresh and aged) originated to the west and northeast. Because the Pacific Ocean is located to the west of the sampling site and the San Francisco Bay is to the northeast, this result supports the sea salt assignments.

In Figure 9, a comparison of the predicted $\mathrm{PM}_{2.5}$ contributions from all sources with measured $\mathrm{PM}_{2.5}$ concentrations shows that the PMF-resolved sources effectively reproduce the measured values and account for most of the variation in the $\mathrm{PM}_{2.5}$ concentrations (4th Street: $\mathrm{R}^{2}=0.955$; Jackson Street: $\left.\mathrm{R}^{2}=0.953\right)$.

Tables 3 and 4 showed the average source contributions of all of the sources identified during the sampling period in two sampling sites. The average concentration 
( \pm standard error) of $\mathrm{PM}_{2.5}$ calculated using the PMF modeling at the 4 th Street and Jackson Street was $14.75 \pm$ $0.65 \mu \mathrm{g} / \mathrm{m}^{3}$ and $14.38 \pm 0.65 \mu \mathrm{g} / \mathrm{m}^{3}$ (the average $\mathrm{PM}_{2.5}$ concentration observed $14.73 \mu \mathrm{g} / \mathrm{m}^{3}$ and $14.35 \mu \mathrm{g} / \mathrm{m}^{3}$ ). For 4th Street, the largest source was wood combustion accounting for $32.1 \%\left(4.73 \pm 0.38 \mu \mathrm{g} / \mathrm{m}^{3}\right)$ of the $\mathrm{PM}_{2.5}$ mass. Secondary nitrate and secondary sulfate were the other large anthropogenic contributions to the fine particle mass. At Jackson Street, the contribution of the wood combustion source was $33.6 \%\left(4.84 \pm 0.37 \mu \mathrm{g} / \mathrm{m}^{3}\right)$. This source had also the largest effect on the local ambient air quality, followed by secondary nitrate $(20.3 \%, 2.92 \pm$ $\left.0.28 \mu \mathrm{g} / \mathrm{m}^{3}\right)$, secondary sulfate $(13.9 \%, 1.99 \pm 0.13 \mu \mathrm{g} /$ $\left.\mathrm{m}^{3}\right)$, aged sea salt $\left(12.4 \%, 1.76 \pm 0.10 \mu \mathrm{g} / \mathrm{m}^{3}\right)$, and gasoline vehicle source $\left(8.3 \%, 1.20 \pm 0.09 \mu \mathrm{g} / \mathrm{m}^{3}\right)$, respectively. Also, Tables 3 and 4 show the comparison of the average source contributions during the summer and winter. Contributions of wood combustion and secondary nitrate at the two sampling sites in winter were much higher than in summer. The contribution of secondary sulfate and aged sea salt source were higher in summer than in the winter at each site. Gasoline vehicle emissions and road dust do not show strong seasonal tendencies.

The contributions of wood combustion, secondary nitrate, secondary sulfate, fresh sea salt, gasoline vehicle, and diesel emission source showed similar results between 4 th Street and Jackson Street. The road dust source and Ni-related industrial source contributions at 4th Street $\left(0.99 \pm 0.10 \mu \mathrm{g} / \mathrm{m}^{3}\right.$ and $\left.0.37 \pm 0.06 \mu \mathrm{g} / \mathrm{m}^{3}\right)$ were $\sim 3.7$ times and 2.1 times higher than at Jackson Street $(0.27 \pm$ $\left.0.02 \mu \mathrm{g} / \mathrm{m}^{3}, 0.18 \pm 0.02 \mu \mathrm{g} / \mathrm{m}^{3}\right)$. By comparison, the average Ni concentration at 4 th Street $\left(16.4 \pm 2.5 \mathrm{ng} / \mathrm{m}^{3}\right)$ was $\sim 2$ times higher than the average Ni concentration at Jackson Street $\left(8 \pm 0.9 \mathrm{ng} / \mathrm{m}^{3}\right)$. On the other hand, the mean aged sea salt contribution at Jackson Street (1.76 \pm $\left.0.10 \mu \mathrm{g} / \mathrm{m}^{3}\right)$ was $\sim 1.7$ times higher than 4 th Street $(1.01$ $\left.\pm 0.06 \mu \mathrm{g} / \mathrm{m}^{3}\right)$.

The average contributions of emitting natural sources in 4th Street and Jackson Street (fresh sea salt + aged sea salt) were $2.14 \mu \mathrm{g} / \mathrm{m}^{3}$ (14.5\%) and $2.52 \mu \mathrm{g} / \mathrm{m}^{3}(17.5 \%)$, respectively. The average contributions of anthropogenic sources at 4 th Street and at Jackson Street were $12.6 \mu \mathrm{g} / \mathrm{m}^{3}$ $(85.5 \%)$ and $11.86 \mu \mathrm{g} / \mathrm{m}^{3}(82.5 \%)$, respectively. Given the interyear variability in meteorology and source emissions, the results from the two sites are quite comparable to one another and could probably be combined into a single analysis.

\section{CONCLUSIONS}

In this study, data from $\mathrm{PM}_{2.5}$ samples collected at the 4th Street and the Jackson Street STN sites in San Jose were analyzed to compare the results from these two nearby sites that were operated sequentially to ascertain if the movement of the site by $\sim 1 \mathrm{~km}$ made a significant change in the nature and apportionment of the sources. Nine sources were resolved from the data for each sampling site including wood combustion, secondary nitrate, secondary sulfate, fresh sea salt, gasoline vehicle, aged sea salt, road dust, diesel emission, and Ni-related industrial source, respectively. The contributions of the identified sources showed similar average results at both 4th Street (initial site) and Jackson Street (relocated site) and were quite comparable with one another, although there was more sulfate observed at Jackson Street than at the 4th Street site. Given the interyear variability in meteorology and source emissions, the results from the two sites are quite comparable to one another and could probably combined into a single analysis. The study of the combined dataset will be the subject of a future study.

\section{ACKNOWLEDGMENTS}

This work was supported by the California Air Resources Board under contract 04-326 and partly supported by the Korea Research Foundation Grant (KRF-2005-D00034M01-2005-000-10022-0).

\section{REFERENCES}

1. Cheung, H.C.; Wang, T.; Baumann, K.; Guo, H. Influence of Regional Pollution Outflow on the Concentrations of Fine Particulate Matter and Visibility in the Coastal Area of Southern China; Atmos. Environ. 2005, 39, 6463-6474

2. Sanderson, M.G.; Collins, W.J.; Johnson, C.E.; Derwent, R.G. Present and Future Acid Deposition to Ecosystems: the Effect of Climate Change; Atmos. Environ. 2006, 40, 1275-1283.

3. Chan, Y.C.; Simpson, R.W.; Mctainsh, G.H.; Vowles, P.D.; Cohen, D.D.; Bailey, G.M. Source Apportionment of Visibility Degradation Problems in Brisbane (Australia) Using the Multiple Linear Regression Techniques; Atmos. Environ. 1999, 33, 3237-3250.

4. Calcabrini, A.; Meschini, S.; Marra, M.; Falzano, L.; Colone, M.; Berardis, B.D.; Paoletti, L.; Arancia, G.; Fiorentini, C. Fine Environmental Particulate Engenders Alterations in Human Lung Epithelial; Environ. Res. 2004, 95, 82-91.

5. Harrison, R.M.; Yin, J. Particulate Matter in the Atmosphere: Which Particle Properties Are Important for Its Effects on Health? Sci. Total Environ. 2000, 249, 85-101.

6. U.S. Environmental Protection Agency. Guideline on Speciated Particulate Monitoring; U.S. Environmental Protection Agency: Research Triangle Park, NC, 1998.

7. Particulate Matter (PM2.5) Speciation Guidance (Final Draft); U.S. Environmental Protection Agency: Research Triangle Park, NC, 1999

8. Andrea, D.A.C.; Artaxo, P. Wintertime and Summertime Sao Paulo Aerosol Source Apportionment Study; Atmos. Environ. 2001, 29, 48894902 .

9. Vega, E.; Garcia, I.; Apam, D.; Ruiz, M.E.; Barbiaux, M. Application of a Chemical Mass Balance Receptor Model to Respirable Particulate Matter in Mexico City; J. Air \& Waste Manage. Assoc. 1997, 47, 524529.

10. Chow, J.C.; Liu, C.S.; Cassmassi, J.; Watson, J.G.; Lu, Z.; Pritchett, L.C. A Neighborhood-Scale Study of PM10 Source Contributions in Rubidox, CA; Atmos. Environ. 1992, 26A, 693-706.

11. Zelenka, M.P.; Wilson, W.E.; Chow, J.C.; Lioy, P.J. A Combined TTFA/ CMB Receptor Modeling Approach and Its Application to Air Pollution Sources in China; Atmos. Environ. 1994, 28, 1424-1435.

12. Ramadan, Z.; Eickhout, B.; Song, X.H.; Buydens, L.M.C., Hopke, P.K. Comparison of Positive Matrix Factorization and Multilinear Engine for the Source Apportionment of Particulate Pollutants; Chemom. Intell. Lab. Syst. 2003, 66, 15-28.

13. Song, X.H.; Polissar, A.V.; Hopke, P.K. Source of Fine Particle Composition in the Northeastern US; Atmos; Environ. 2001, 35, 5277-5286.

14. Paatero, P. Least Squares Formulation of Robust Non-Negative Factor Analysis; Chemom. Intell. Lab. Syst. 1997, 37, 23-35

15. Lee, J.H.; Yoshida, Y.; Turpin; B.J.; Hopke, P.K.; Poirot, R.L.; Lioy, P.J.; Oxley, J.C. Identification of Sources Contributing to Mid-Atlantic Regional Aerosol; J. Air \& Waste Manage. Assoc. 2002, 52, 1186-1205.

16. Zhou, L.; Kim, E.; Hopke, P.K.; Stanier, C.; Pandis, S. Advanced Factor Analysis on Pittsburgh Particle Size Distribution Data; Aerosol Sci. Technol. 2004, 38, 118-132.

17. Maykut, N.N.; Lewtas, J.; Kim, E.; Larson, T.V. Source Apportionment of $\mathrm{PM}_{2.5}$ at an Urban IMPROVE Site in Seattle; Environ. Sci. Technol. 2003, 37, 5135-5142.

18. Kim, E.; Hopke, P.K.; Larson, T.V.; Covert, D.S. Analysis of Ambient Particle Size Distributions Using Positive Matrix Factorization and Unmix; Environ. Sci. Technol. 2004, 38, 202-209.

19. California Air Resources Board. The California Almanac of Emissions and Air Quality, 2005 ed.; California Air Resources Board: Sacramento, CA, 2005.

20. U.S. Environmental Protection Agency. Available at: http:// www.epa.gov/air/data (accessed 2005).

21. Quality Assurance Project Plan Chemical Speciation of PM2.5 Filter Samples; EAP-68/D-03-038; U.S. Environmental Protection Agency: Research Triangle Park, NC, 2005. 
22. Birch, M.E.; Cary, R.A. Elemental Carbon-Based Method for Monitoring Occupational Exposures to Particulate Diesel Exhaust; Aerosol Sci. Technol. 1996, 25, 221-241.

23. Polissar, A.V.; Hopke, P.K.; Paatero, P; Malm, W.C.; Sisler, J.F. Atmospheric Aerosol over Alaska 2. Elemental Composition and Sources; J. Geophys. Res. 1998, 103, 19045-19057.

24. Lee, E.; Chun, C.K.; Paatero, P. Application of Positive Matrix Factorization in Source Apportionment of Particulate Pollutants; Atmos. Environ. 1999, 33, 3201-3212.

25. Ramadan, Z.; Song, X.H.; Hopke, P.K. Identification of Sources of Phoenix Aerosol by Positive Matrix Factorization; J. Air \& Waste Manage. Assoc. 2000, 50, 1308-1320.

26. Polissar, A.V.; Hopke, P.K.; Poirot, R.D. Atmospheric Aerosol over Vermont: Chemical Composition and Sources; Environ. Sci. Technol. 2001, 35, 4604-4621.

27. Kim, E.; Hopke, P.K.; Qin, Y. Estimation of Organic Carbon Blank Values and Error Structures of the Speciation Trends Network Data for Source Apportionment; J. Air \& Waste Manage. Assoc. 2005, 55, 11901199.

28. Kim, E.; Hopke, P.K.; Edgerton, E.S. Source Identification of Atlanta Aerosol by Positive Matrix Factorization; J. Air \& Waste Manage. Assoc. 2003, 53, 731-739.

29. Kim, E.; Hopke, P.K. Comparison between Conditional Probability Function and Nonparametric Regression for Fine Particle Source Directions; Atmos. Environ. 2004, 38, 4667-4673.

30. Hopke, P.K. A Guide to Positive Matrix Factorization; In Workshop on UNMIX and PMF as Applied to PM2.5; 600/A-00/048; Willis, R.D., Ed.; U.S. Environmental Protection Agency: Research Triangle Park, NC, 2000.

31. Paatero, P.; Hopke, P.K.; Begum, B.A.; Biswas, S.K. A Graphical Diagnostic Method for Assessing the Rotation in Factor Analytical Models of Atmospheric Pollution; Atmos. Environ. 2005, 39, 193-201.

32. Tolocka, M.P.; Solomon, P.A.; Mitchell, W.; Norris, G.A.; Gemmill, D.B.; Wiener, R.W.; Vanderpool, R.W.; Homolya, J.B.; Rice, J. East Versus West in the US: Chemical Characteristics of PM2.5 during the Winter of 1999; J. Aerosol Sci. Technol. 2001, 34, 88-96.

33. Paatero, P.; Hopke, P.K. Discarding or Downweighting High-Noise Variables in Factor Analytic Models; Anal. Chim. Acta 2003, 490, 277-289.

34. Hopke, P.K.; Lamb, R.E.; Natusch, D.F.S. Multielemental Characterization of Urban Roadway Dust; Environ. Sci. Technol. 1980, 14, 164-172.

35. Shah, S.D.; Cocker, D.R., III; Wayne, J.M.; Norbeck, J.M. Emission Rates of Particulate Matter and Elemental and Organic Carbon from In-Use Diesel Engines; Environ. Sci. Technol. 2004, 38, 2544-2550.

36. Hopke, P.K. Receptor Modeling in Environmental Chemistry; John Wiley \& Sons: New York, NY; 1985

37. Qin, Y.; Oduyemi, K.; Chan, L.Y. Comparative Testing of PMF and CFA Models; Chemom. Intell. Lab. Syst. 2002, 61, 75-87.
38. Seinfeld, J.H.; Pandis, S.N. Atmospheric Chemistry and Physics, from Air Pollution to Climate Change. John Wiley \& Sons: New York, NY; 1998.

39. lander, T.; Antikainen, E.; Raunemaa, T.; Elonen, E.; Rautiola, A.; Torkkell, K. Particle Emissions from a Small Two-Stroke Engine: Effects of Fuel, Lubricating Oil, and Exhaust Aftertreatment on Particle Characteristics; Aerosol Sci. Technol. 2005, 39, 151-161.

40. Garg, B.D.; Cadle, S.H.; Mulawa, P.A.; Groblicki, P.J. Brake Wear Particulate Matter Emissions; Environ. Sci. Technol. 2000, 34, 4463-4469.

41. Wahlin, P.; Berkowicz, R.; Palmgren, F. Characterisation of TrafficGenerated Particulate Matter in Copenhagen; Atmos. Environ. 2006, 40, 2151-2159.

42. Ames, M.R.; Gullu, G.; Beal, J.; Olmez, I. Receptor Modeling for Elemental Source Contributions to Fine Aerosols in New York State; J. Air \& Waste Manage. Assoc. 2000, 50, 881-887.

43. Jang, M.; Lee, S.; Kamens, R.M. Organic Aerosol Growth by AcidCatalyzed Heterogeneous Reactions of Octanal in a Flow Reactor; Atmos. Environ. 2003, 37, 2125-2138.

44. Gray, H.A.; Cass, G.R. Source Contributions to Atmospheric Fine Carbon Particle Concentrations; Atmos. Environ. 1998, 32, 3805-3825.

45. Fairley, D. Sources of Bay Area Fine Particles: a Chemical Mass Balance Analysis; BAAQMD Draft Technical Report; Bay Area Air Quality Management District: San Francisco, CA; 2005.

46. Chow, J.C.; Fairley, D.; Watson, J.G.; DeMandel, R.; Fujita, E.M.; Lowenthal, D.H.; Lu, Z.; Frazier, C.A.; Long, G.; Cordova, J. Source Apportionment of Wintertime $\mathrm{PM}_{10}$ at San Jose, Calif; J. Environ. Eng. 1995, 121, 378-387.

\section{About the Authors}

InJo Hwang is a research associate with the Center for Air Resources Engineering and Science and Philip K. Hopke is the Bayard D. Clarkson Distinguished Professor with the Department of Chemical and Biomolecular Engineering at Clarkson University. Address correspondence to: Philip K. Hopke, Department of Chemical Engineering, Clarkson University, Box 5708, Potsdam, NY 13699-5708; phone: +1-315268-3861; fax: +1-315-268-4410; e-mail: hopkepk@clarkson. edu. 